\title{
IMPLEMENTATION OF MATERNAL AND NEONATAL ELIMINATION PROGRAM AT BANJARMASIN HEALTH CENTER, SOUTH BORNEO, INDONESIA
}

\author{
Susanti Suhartati, Lisda Handayani \\ Professional Education for Midwives, Faculty of Health, Sari Mulia University
}

\begin{abstract}
Background: Increasing tetanus toxoid (TT) coverage with the implementation of the Maternal and Neonatal Tetanus Elimination (MNTE) program was intended to prevent tetanus in women and infants. All Health Centers implement the MNTE program as the first service for the implementation of TT. This study aimed to describe the causes of low TT coverage at Community Health Center in Banjarmasin and the obstacles in implementing the Maternal and Neonatal Tetanus Elimination (MNTE) program.

Subjects and Method: This was a descriptive study with cross-sectional design conducted in Banjarmasin Health Center, South Borneo, from February to August 2021. A total of 150 pregnant women and 25 midwives were selected for this study by accidental sampling. Data were collected by questionnaire and analyzed descriptively.

Results: A total of 28 (18.7\%) pregnant women never received TT immunization, 6 pregnant women (4\%) with TT 4 status, and 54 pregnant women (36\%) pregnant women with TT 1 status. A total of 78 pregnant women (52\%) had poor knowledge of TT immunization. 88 pregnant women (58.6\%) had negative attitudes towards TT immunization, $59.4 \%$ of pregnant women stated that the role of officers was still lacking in explaining TT immunization. Documentation of immunization services was only centered on service providers, and was inaccessible or iilegible by service recipients. Low parity needed more efforts in promoting TT immunization. Lack of information and knowledge had caused negative attitudes towards immunization among pregnant women.

Conclusion: Increasing promotion efforts and media documentation are needed in optimizing MNTE services at the Banjarmasin Health Center.
\end{abstract}

Keywords: tetanus toxoid, immunization, Maternal and Neonatal Tetanus Elimination

\section{Correspondence:}

Susanti Suhartati. Professional Education for Midwives, Faculty of Health, Sari Mulia University. Jl. Pramuka 2, Banjarmasin, South Borneo, Indonesia. Email: suhartatisusanti@gmail.com. Mobile: +62 823-1238-3320

The $8^{\text {th }}$ International Conference on Public Health Solo, Indonesia, November 17-18, $2021 \mid 55$ 